\title{
Şemsiyye Fi’ı Hisab Adlı Eserin Geometri Konularının Matematik Öğretimi Bakımından 2017 Ortaöğretim Matematik Dersi Öğretim Programı ile Karşılaştırılması*
}

\section{Kamil ARI** Ebru ÜNÜVAR ${ }^{* * *}$}

Öz: Matematik tarihi, modern matematiğin gelişiminin ve geçirmiş olduğu safhaların görülmesi açısından önemli bir yere sahiptir. Son yıllarda matematik tarihi, ulusal ve uluslararası birçok çalışmaya konu olmakta ve matematik tarihinin matematik öğretimi ile ilişkilendirilmesi yönünde çalışmalar yapılmaktadır. Medeniyet tarihimizde önemli bir yere sahip olan Osmanlı Devleti ise zamanın önemli ilim ve kültür medeniyetlerinden birisidir. Osmanlı Devleti'ndeki ilim faaliyetlerine verilen önem göz önüne alınarak dönemin ilim merkezlerinde öğretimi yapılan Nizâmuddin Nîsaburi’nin Şemsiyye Fi'lHisab adlı eseri incelenmiştir. $\mathrm{Bu}$ esere konu olan geometri hesapları ve öğretimi incelenerek günümüz ortaöğretim matematik öğretim programı ile karşılaştırılması yapılmıştır. Araştırma da doküman analizi yöntemi kullanılmıştır. Şemsiyye Fi'l-Hisab adlı eserin transkripsiyonu yapılarak Arapçadan Türkçe 'ye tercümesi yapılmıştır. Araştırmada eserin anlaşılmasını kolaylaştırmak adına modern matematik sembol ve işaretleri kullanılmıştır. Araştırma sonucunda eserde kullanılan geometri konularının içeriği, hesap yöntemleri ve öğretim yöntem ve teknikleri ile 2017 Ortaöğretim Matematik Dersi Öğretim Programı arasında benzerlik ve farklılıklar ortaya konulmuştur.

Anahtar Kelimeler: Şemsiyye Fi'l Hisab, Matematik Tarihi, Geometri, Matematik Öğretimi

\footnotetext{
* Bu çalışma Ebru ÜNÜVAR'ın yayımlanmamış yüksek lisans tezinden üretilmiştir.

** Doç. Dr., Selçuk Üniversitesi, Eğitim Fakültesi, Matematik Eğitimi Anabilim Dalı, email:kamilari@yahoo.com Orcid No: 0000-0003-4691-9621

*** Öğretmen, MEB, email: ebruydrm91et@gmail.com, Orcid No: 0000-0002-9053-3833
} 


\section{The Comparison of the Geometry Topics of the Work Called Şemsiyye Fi'l Hisab with the 2017 Secondary School Mathematics Curriculum in Terms of Teaching Mathematics}

Abstract: The history of mathematics has an important role in understanding the development of modern mathematics and the stages in which it has passed. Recently, the history of mathematics has been subject to many national and international studies and these studies have been made to link the history with the teaching of mathematics. Regarding the value given to scientific activities in the Ottoman State, which is one of the states in our civilization history, the work of Nizâmuddin Nîsabûrî named Şemsiyye Fi'lHisab, which was taught in medresses during this period, was studied on the basis of calculations and teaching of geometry and high school mathematics curriculum. Document analysis method was used in the research. Transcription of the work Şemsiyye Fi'l-Hisab was made and translated from Arabic to Turkish. In the research modern mathematical symbols and signs have been used to ease understanding of the work. As a result, similarities and differences were found between 2017 Secondary School Mathematics Curriculum and the contents of the geometric topicss used in the work, the calculation and teaching methods and techniques.

Keywords: Şemsiyye Fi'l Calculation, History of Mathematics, Geometry, Mathematics Teaching.

\section{Giriş}

Matematik insanlık tarihinin en eski bilimlerinden biridir. Eskiden sayılar ve semboller bilimi olarak algılanan matematik zamanla artık bir tanıma sığmayacak kadar geniş bir perspektife sahip olmuştur (Ülger, 2005). Matematik, soyut bir bilim olmakla beraber matematiğin temel konusu da sayılar ile çevremizde görebildiğimiz şekillerdir. Sembol ve şekil kullanılır, uygulama alanı geniş, kesin sonuç esasına dayanır. Kesin kanunları vardır. Kendisini devamlı yeniler, diğer bilimlerde yapılan çalışmaları, kanunlar halinde ifade edilebilir duruma getirir. Diğer ilgili bilim dalları ile bağımlı olarak sürekli bir gelişme gösterir ve gelişmeler birbirini tamamlar. Genelde bağımsız bir bilim dalı olup uygulanabilirliği geniştir. Matematik, bilgileri genelleştirme ile ortaya koyar ve elde ettiği sonuçlar için hipotezler kurar ve onları ispatlamak ister (Göker, 1989). Matematik bu denli gelişen ve kendini yenileyen bir yapıya sahip olduğundan yeni 
nesillere matematiğin bazı kavramlarının tarihinî gelişiminden bahsetmek ve onları matematik uğraşlarına yönlendirilmesi bakımından yararlı olacağı düşünülmektedir.

Matematik tarihi, genel olarak matematiksel bilginin nasıl medeniyetler boyunca elden ele devrilerek büyüdüğünü ve geliştiğini gösteren bilgiler sunar (Baki, 2014). (Göker, 1989)’ göre, “matematik tarihi, matematikte bugün 544 ayrı dalı olduğu kabul edilen bilim dallarının doğuşlarından başlayarak gelişimini inceleyen bir bilim dalıdır. Konusu, matematikte sayı, sayma ve şekil kavramını kapsayan konuların, başlangıçtan bugüne kadar gelişimini, bilimsel düşünce ve kronolojik bir çerçevede sergilemektir." biçiminde açıklamada bulunmuştur. Bu konu da ünlü matematikçi Alman düşünür G.W. (Leibniz ,1646-1716), “Bende o kadar fikir var ki, benden daha iyi görmesini bilenler bir gün onları daha da derinleştirecek ve benim zihin emeğime kendi kafalarının güzelliğini katacaklardır.” demiştir. G.W. Leibniz’in sözleri şüphesiz zamanında elde edilen matematiksel bilgilerin durağan olmadığını, üzerine yapılacak katkılarla kendini yenileyerek gelişebileceğinden bahsetmiştir. Bu açıdan bakıldığında Matematik biliminin tarihinin bilinmesi keşfedilen birçok bilgiyi saf halde gösterirken keşfedilecek birçok bilginin de kapılarını aralamaktadır.

Matematik tarihi incelenirken herhangi bir millet ya da topluluğa bütün matematiksel buluşların patentini vermek doğru olmaz. Matematik tarihi ve bilim tarihleri incelendiğinde medeniyetler birbirleri ile bilgi ve kültürel etkileşimi doğal olarak olmuştur. Bu noktada her medeniyetin ortak bir uğraşı sonucu oluşan matematik için matematik tarihinde varsa eksik kalmış noktaların fark edilerek tamamlama yoluna gitme akılcı olmaktadır. Yunanistan matematiğinde felsefi çalışmalar, Mısır matematiğinde işlemler ve kavramlar, Hint matematiğinde sayılar ön planda iken Arap ve İslam-Türk dönemi matematiğinde daha çok arazi hesaplamaları ön plana çıkmıştır.

İslâm medeniyetinde hem dinî hem idarî hem de içtimaî hayatta hedeflenen mükemmellik, dolayısıyla dinî ve içtimaî meşruiyet bir yönüyle matematik bilimlere ve bunu sağlayan aletlere dayanır. İbadet zamanlarının ayarlanması, Mekke'de bulanan Kâbe’nin geometrik-trigonometrik yönünün tayin edilmesi, başta Ramazan ayı olmak üzere dinî ay ve günlerin başlangıç ve sonlarının belirlenmesi, tereke ve miras hesaplarının yapılması, arazi ölçümlerinin ayarlanması, nizam-1 devlet için maliye işlerinin düzenlenmesi ve mimarî gibi pek çok konunun matematik bilimleri gerektirdiği izahtan varestedir (Fazlıoğlu, 2009). Bu çerçevede kadim devirde matematiğin üç yönlü 
bir işleve sahip olduğu söylenebilir. Birincisi aritmetik yahut geometrik yaklaşımları esas alan felsefî tavırdır. Bu tavır varlığı sayısal (adedî) veya geometrik (hendesî) tasavvur etmeye yöneltmiş, bu da başta sayısal (adedî) ya da geometrik (hendesî) sayılar teorisi olmak üzere pek çok matematik teoremin ortaya çıkmasına sebep olmuştur. İkincisi, sayısal ve geometrik matematiğin başta astronomi olmak üzere diğer bazı disiplinlere uygulanmasıdır. Bu yön, özellikle astronomi disiplininin gerektirdiği pek çok yeni matematik tekniğin ortaya çıkmasına yol açmıştır. Üçüncüsü matematiğin hem aritmetik hem de geometri yönünün sosyal ve siyasî hayatta arazi ölçümü, vergi sistemi, mesafe ölçümü gibi pek çok konuda kullanılmasıdır (Fazlıŏlu, 2009).

Bu çalışmada yukarıda belirtilen ifadelere ek olarak Osmanlı Devleti döneminden bir eserin tercih edilmesinin nedeni sözde karanlık çağın aydınlatılmasına katkıda bulunarak var olan matematik ilmini gün yüzüne çıkarmaya yardımcı olmaktır. Dönemin matematik ilminin incelenmesi için eserin sadece Türkçe 'ye çevrilmesi yeterli olmamaktadır. Bu tür bir çeviri tarih bilimi açısından önemli bir çalışma ve kaynak teşkil etse de bilim tarihi açısından yeterli değildir. O halde eserin bulunduğu kültürel, sosyal, idari ve iktisadi yapı dönemin iliminin incelenmesinde önemli yer oluşturmaktadır. Nihayetinde eski Türkçe ile ifade etmek gerekirse eserin şerhlerini yazmak gerekmektedir. Böylece hem tarih bilimi hem de matematik bilimi açısından kaynak teşkil edecek bir çalışma ortaya koyulabilir.

(Mefail Hızlı, 2008), İslâm tarihinin en dikkat çeken eğitim-öğretim kurumu medreselerdir. Biçimindeki açıklamasına dayanarak bahsi geçen dönemin ilme bakış açısı bu alanda incelenebilir. Osmanlı medreselerinde XVI. yüzyılın ortalarına kadar müderrisin merkezde olduğu bir sistem hâkim idi. Aslında bu gelenek Osmanlılardan önce de vardı. Eğitim-öğretim faaliyetleri, devlet tarafından sınırları ve muhtevası net olarak belirlenmemiş ve vakıf kurucusunun kısmen tespit ettiği, ama daha çok geleneğin yönlendirdiği bir biçimde yürütülmüştü. Devlet, medreseleri sadece yakından takip etmeye çalışıyor, ama müdahale mekanizmasını büyük ölçüde işletmiyordu. Bizzat müderrisin nezaretinde yürütülmekte olan derslerin işlenmesi, seçilen kitabın takip edilmesi tarzında olurdu. Belli sürede okunması gereken kitap ya da kitapların belirli bölümleri tamamlanmadıkça başka bir derse geçilmesi söz konusu değildi. Bu anlamda medreselerde sınıf geçme değil, ders/kitap geçme yöntemi uygulanmaktaydı. Dersler, her 
biri için esas olarak alınmış olan bir veya birkaç ana kitap üzerinde takrir yoluyla yapılırdı ve dersler bu kitapların adı ile anılırdı (Unat, 1964).

Geometrinin insan hayatına etkisi, M.Ö. 4000 yıllarına uzayacak kadar eskidir. Yapılan araştırmalar sonucunda, zamanımızdan 6000 yıl kadar önceleri, Eski Mısırlıların düzgün olmayan, Mezopotamyalıların da dikdörtgen şekkindeki arazilerin alanlarını tespit etmeyi bildikleri anlaşılmıştır (Göker, 1989). Geometri, uzaydaki nokta, eğri, yüzey ve cisimlerin şekilleri ve ölçümleriyle ilgilenen matematik dalıdır. Geometri, elemanların bazı dönüşümler altında değişmez kalan özellikleri inceler (Demirtaş, 1986).

Yine bu çalışmanın matematik eğitimi açısından incelenmiş olması Osmanlı medeniyetinin hızla gelişip neredeyse dünyanın yarısına hükmettiği dönemlerde yetişen devlet erkânının eğitimi hakkında fikir verecek olması bakımından önemlidir. Bu sayede yapılan matematik eğitiminin dönemdeki ilim adamlarının sahip olduğu matematik bilgisiyle ne derece harmanlandığı hakkında yorum yapılabilecektir. Bu çalışmada Şemsiyye fi'l-Hisâb adlı matematik risalesinin matematik tarihi ve matematik eğitimi açısından incelenerek günümüz matematik eğitim öğretim müfredatı çerçevesinde hendese (geometri) hakkında ilim faaliyetleri ve eğitimi incelenecektir.

Osmanlı Devleti'nde geometri ilmine verilen önem için dönemde gerçekleşen bir olayı incelemek geometri ilmine bakış açısının görülmesinde faydalı olacaktır.

'Bir kimse boyu ve eni yüz zirâ olmak üzere bir tarlayı başkasına satıp teslim edeceği zaman boyun ve eni ellişer zirâ iki tarla verdi. Aralarında uyuşmazlık çıkıp bir kadıya vardılar ki hendese bilmezdi. Hakkı budur diye hükmeyledi. Sonra hendese bilen bir kadı bulup dinlettiler, yarım hakkıdır dedi. Doğrusu da budur. Bunların aslını bilmek isteyen riyâziyat görmeye heves eyleye (İzgi, 1997). Burada bahsi geçen hendese Osmanlı Devleti zamanında geometri olarak anılmaktaydı. Matematiğin ana dallarından biri olan Geometri, uygulama kısmı çok geniş bir alana sahiptir. O dönemin matematiğe bakış açısı genel mana da yararcılık olduğundan geometriye verilen önem aşikârdır.

(Baga, 2007)'ya göre, Türk bilim tarihinin kurucularından sayılan Salih Zeki Âsâr-1 Bâkiye'sinde Şemsiyye'nin Osmanlı'da okutulan orta hacim ve derecedeki hesap kitapları arasında olduğunu ifade eder (Zeki, 2003). Son dönem eserler arasından Cevat

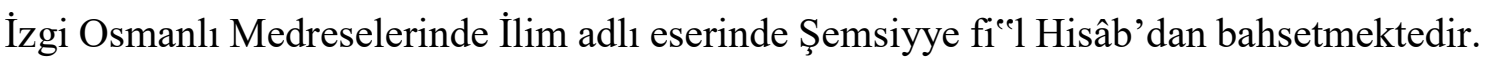


Eserin Arapça'dan Türkçe'ye çevrimi 2007 yılında Elif Baga tarafından 'Nizâmuddin Nisâbûrî ve Şemsiyye Fi’l Hisâb Adlı Matematik Risalesinin Tahkik, Tercüme ve Tarihi Değerlendirmesi’ yüksek lisans tezinde yapılmıştır.

Eş-Şemsiyye fie ${ }^{\text {ec }}$-Hisâb mukaddime ve iki fenn'den oluşmaktadır. Ancak ikinci fenn'den sonra ayrıca bir teznîb bölümü eklenmiştir. İki fasıldan meydana gelen mukaddimede hisâbın tanımı ve konusu, doğal ve rasyonel sayıların tarifi, sayıların şekilleri ve basamakları konularına yer verilmiştir. İki bâbdan oluşan ilk fenn genel olarak hisâbın ana konularına dairdir. Birinci bâbda tam sayılarla iki katını alma, yarıya bölme, toplama, çıkarma, çarpma ve bölme işlemlerinin nasıl yapıldığı cetveller yardımıyla anlatılmaktadır. İkinci bâb ise rasyonel sayıların hesabına ayrılmıştır. Burada rasyonel sayıların paydalarının açıklanması, irrasyonel sayılar, basit, bileşik ve tamsayılı kesirler ile çarpma, bölme, toplama ve çıkarma bahisleri izah edilmektedir. İlk fenne nispetle daha ileri seviye konuların açıklandığı ikinci fenn dört bâbdır. İlk bâbda üslü ve köklü sayılar ile sayıların köklerinin bulunması anlatılmaktadır. İkincibâbda ebced harfleri ve karşıllı̆ı olan sayılar, sittînî (müneccimîn) hesâbında iki katınıalma, yarıya bölme, toplama, çıkarma, çarpma, bölme ve kök bulma işlemleri cetvellerile açıklanmaktadır. Üçüncü bâb mesâha bahsine tahsis edilmiştir. Burada 'nokta', ‘doğru', ‘yüzey', 'açı' gibi kavramların tarifi verilmekte daha sonra şekil ve cisimler tarif edilmekte son olarak da bu şekil ve cisimlerin alan ve hacim hesaplamaları izah edilmektedir. İkinci fennin son bâbı olan dördüncü bâbda ise cebr ve mukâbele yolu ile bilinmeyenli ifadelerin çözümü verilmektedir. Buna göre üslü ve köklü ifadelerle çarpma, bölme, toplama ve çıkarma işlemlerinin yapılması, birinci ve ikinci dereceden denklemlerin çözüm kümelerinin bulunması ve altı cebirsel denklem konuları burada yer almaktadır. Son olarak teznîb bölümünde ise çift yanlış hesâbı ve mîzan (sağlama) konuları anlatılmıştır.

Bu çalışmada, Osmanlı Devleti'nde Fatih dönemi medreselerinde okutulmuş olan Nizameddin Nasuburi'nin El Şemsiyye Fil-Hisab isimli eseri incelenerek matematik bilimi ve eğitimi açısından değerlendirmesi ile birlikte 2017 MEB müfredatı karşılaştırılacaktır.

\section{Problem Durumu}

Bahsi geçen çalışmamızda, Şemsiyye fi'l-Hisâb adlı eserin geometri konularının içeriği ve öğretimi ile günümüz matematik ve öğretimi arasındaki benzerlik ve farklılıklar nelerdir? Ayrica, 
1) Şemsiyye fi'l-Hisâb adlı eserinde bulunan geometri konularının içeriği nelerdir ve bu konuların öğretimi nasıldır?

2) Şemsiyye fi'l-Hisâb adlı eserin medreselerde okutulan bir kitap olma hususunda günümüz Milli Eğitim bünyesinde bulunan ve okullarda okutulan ders kitapları arasinda benzerlik ve farkliliklar nelerdir?

3) Şemsiyye fi'l-Hisâb adlı eserde geometri öğretimi ile günümüzdeki geometri öğretimi arasında farklılıklar nelerdir?

4) Şemsiyye fi'l-Hisâb adlı eserde bulunan geometri öğretiminde kullanılan 2017 yılında yapılandırılan eğitim öğretim programında öngörülen matematik öğretimi incelendiğinde farklı yöntem ve teknikler mevcut mudur?

soruları problem durumu olarak tespit edilip cevap aranacaktır.

\section{Yöntem}

\section{Araşturma Modeli}

Yapılan araştırmada doküman analizi modeli kullanılmıştır. Bu yöntem için öncelikle Nizâmuddin Nîsaburi'nin Şemsiyye Fi'l Hisab adlı eserinin ilgili kısımlarının Latin harflere transkripsiyonu yapılmıştır. Latin harflere çevrimi yapılan eserin günümüz Türkçesine çevrimi sağlanmıştır. 2017 -2018 Eğitim Öğretim yılı için Millî Eğitim Bakanlığı tarafindan yapılandırılan Ortaöğretim Matematik Öğretim Programı kapsamında Şemsiyye Fi'1 Hisâb adlı eserin içeriği cebir ve geometri öğretimi açısından incelenmiştir

\section{Veri Toplama Araçları}

\section{Transkripsiyon}

Nizâmuddin Nisâbûrî'nin Şemsiyye Fi’l Hisâb adlı eserin tamamının transkripsiyonu yapılmıştır. Şemsiyye Fi'l Hisâb adlı eserin transkripsiyonu yapılırken Arapça bilen bir uzmandan ve ana dili Arapça olan bir tıp öğrencisinden yardım alınmıştır. Eserde kullanılan sayı, sembol ve şekiller, modern matematik notasyonları ile anlatımın tarihi dokusunu bozmadan açıklanmaya çalışılmıştır.

\section{Tercüme}

Nizâmuddin Nisâbûrî'nin Şemsiyye Fi'l Hisâb adlı eserin tamamının transkripsiyonu yapıldıktan sonra günümüzde kullanılan Modern Türkçe’ye çevrimi yapılmıştır. Şemsiyye Fi'1 Hisâb adlı eserin çevrimi yapılırken Arapça bilen bir uzmandan ve ana dili Arapça olan bir tıp öğrencisinden yardım alınmıştır. Eserin çevrimi yapılırken eserde geçen matematik terimleri, ifadeleri, sayı ve şekilleri, notasyonları da günümüz modern matematiğine uygun ifade edilerek eserin anlaşılması sağlanmıştır. 
Orijinal metin ve transkripsiyon-tercüme örneği aşağıdaki biçimdedir:

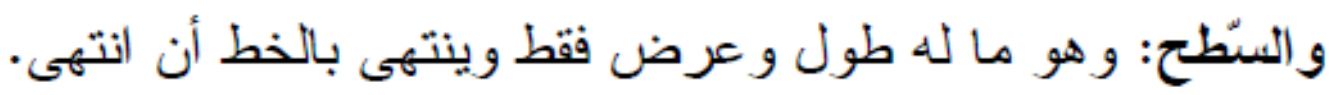

Yüzey(Sath): Sadece uzunluğu ve eni olan, bittiğinde çizgi ile bitendir.

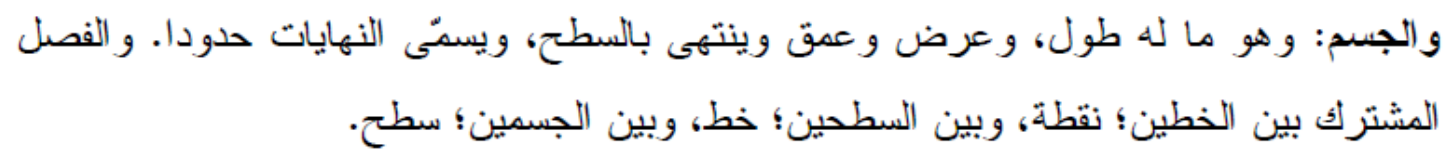

Cisim: Uzunluk, genişlik ve derinliği olandır, yüzeyle biter ve sınırların sonu olarak isimlendirilir. Çizgiler arasındaki ortak fasıl "nokta", yüzeyler arasındaki "çizgi” ve cisimler arasındaki de "düzlem" dir.

\section{Verilerin Çözümlenmesi}

Nizâmuddin Nisâbûrî 'nin Şemsiyye Fi'l Hisâb adlı eserin tamamının transkripsiyonu yapıldıktan sonra günümüzde kullanılan Modern Türkçe'ye çevrimi yapılmıştır. Kitabın matematik ve geometri öğretimi 2017 Eğitim Öğretim Yılı Matematik Dersi Öğretim Programı belirlediği öğretim programı ile karşılaştırılmıştır. Şemsiyye Fi'l Hisâb adlı eserde matematik ve geometri konularında kullanılan farklı yöntem ve teknikler incelenmiştir.

\section{Bulgular ve Yorum}

Bu bölümünde Nizâmuddin Nisâbûrî 'nin Şemsiyye Fi’l Hisâb adlı eserin Latin harflerine Transkripsiyonu yapılmış ve ardından eser günümüzde kullanılan modern Türkçe'ye çevrilmiştir. Elde edilen sonuçlar, 'Giriş' bölümünde belirtilen araştırma problemi ve alt problemleri kıstas alınarak ve sıra gözetimi yapılarak elde edilen sonuçlar belirtilmiştir.

Şemsiyye fi'l-Hisâb adlı eserde bulunan geometri konularının içeriğine ve öğretimine ilişkin bulgular

Eserde verilen matematik öğretiminde konu başlıkları aritmetik, cebir ve geometri olarak 3 ana bölüm etrafında şekillenmiştir. Bu bölümler kendi başlıkları altında bir bütün 
olarak incelenmiştir. Ancak bu çalışma sadece geometri alanının incelenmesini içermektedir. Günümüz ortaöğretim matematik müfredatında ise konular sayılar ve cebir, geometri, veri, sayma ve olasılık alanları etrafında toplanmıştır. Veri, sayma ve olasılık öğrenme alanının eserde olmamasının nedeni; şüphesiz olasılık kavramının ve kullanımının matematik literatürüne geçmesi için 16.yy’a gelinmesi gerektiğindendir.

Eserde matematik öğretimine başlamadan önce bir önsöz verilmektedir. Önsöz k1sminda,

İlim ve edeb tahsil edenler İlm-i Hisâb’a ilgisiz kalamazlar. Ülke ve devlet işlerinin kontrolü ile uğraşanlar, vezirler ve kâtipler ona muhtaçtırlar. Matematik her açıdan önemli ve ihtiyaç duyulan bir ilimdir.

Biçiminde verilen açıklamalar ilmin yararlılığından bahsetmektedir. 2017 ortaöğretim matematik müfredatının vizyonu olan hayata görelik, yararlılık kavramlarına karşı1ık gelen bu açıklamalar aynı zamanda bu ilme talip olan kişileri güdülemek için birebirdir. Aynı zamanda eserin yine önsöz kısmında yer alan,

Eskiden beri kendim ve ilim taliplileri için bir kitap yazmak istiyordum. Bu kitap; külli ve önemli kuralları kuşatacak, araştırmacıyı yoracak gereksiz bilgileri içermeyecek ve âlim bir kişi okuduğunda ona bir şey ekleme ihtiyacı duymayacă̆ bir eser olacaktı.

Ömür kısa, iş çok. Bu yüzden akıllı kişi ömrünü en önemli olan için harcamalı ve her iki dünyada da faydalı olana ilgi göstermelidir. Biçiminde verilen açıklamalar göstermektedir ki matematik ilminin kişinin hayatında uygulayacağı yerler için verilmesi gerekliliğinden bahsetmektedir. $\mathrm{Bu}$ da 2017 ortaöğretim müfredatında yapılan sadeleştirmeler ve matematiğin günlük hayata yaklaştırılması çalışmalarına karşılık gelmektedir.

Eserin geometri bölümü incelendiğinde Geometri ilminin 'mesâha' olarak isimlendirildiği görülmektedir. Eserde geometri öğretimine, geometrinin en temel terimlerinden başlanarak tanımlar verilmektedir.

Eserde 'Nokta: Parçası olmayan şeydir.'biçiminde tanımlanmıştır. Nokta, bugün günümüz ortaöğretim matematik müfredatında tanımsız terim olarak verilmektedir. Ancak birçok sezgisel tanımı verilerek anlamlandırılması sağlanmaktadır. Burada verilen tanımda bir sezgisel tanım olarak kabul edilebilir.

Çizgi (Hat): Sadece uzunluğu olan ve bittiğinde nokta ile bitendir. biçiminde tanımlama yapılmıştır. Çizgi, bugün günümüz ortaöğretim matematik müfredatında 
doğru parçası olarak verilmektedir. Burada verilen tanım oldukça belirsizdir. Bu tanımın şüphesiz dönemin ilim adamları tarafından aynı anlaşıldığı ortadır.

Eserde Yüzey(Sath): Sadece uzunluğu ve eni olan, bittiğinde çizgi ile bitendir. biçiminde verilen açıklama ortaöğretim matematik müfredatında düzlem olarak verilmektedir. Yine düzlemin tanımı verilmemekte ve tanımsız terim olarak tanıtılmaktadır. Ancak bu terimin sezgisel tanımı birçok açıdan verilerek anlamlandırılmaya çalışılmaktadır. Bu tanım sezgisel tanım olarak verilebilir.

Tanımlanan nokta, çizgi ve düzlem terimlerinin ilişkisi tanımlanan 'cisim' terimi ile birlikte verilmiştir. 'Çizgiler arasındaki ortak fasıl “nokta”, yüzeyler arasındaki “çizgi” ve cisimler arasındaki de “düzlem”dir.' Günümüz ortaöğretim matematik öğretiminde doğruların kesişiminden nokta, yüzeylerin kesişiminden doğru, cisimlerin kesişiminden düzlemlerin elde edildiği biçiminde ifade edilmektedir. Eserde;

Doğru (Hat Mustakim):Gözün ışınının uzanımı üzerine düştüğünde ortası ucunu örterse buna "doğru çizgi” denir.

Düzlemsel Yüzey (Sath Müstevî):Bütün yönlerden varsayllan tüm doğruların müstakim olduğu yüzeydir. Ĕ̆ger iki yüzey en ve boy açısından birbirine paralel olursa (birbiriyle buluşmazsa) eşit olarak sonsuza kadar giderler.

Açı (Zâviye): Paralel olmayan iki doğru arasındaki yüzeydir. Bu iki doğrudan biri çıkarılmayıncaya kadar iki doğru birlikte bir açı oluştururlar. Doğrulardan biri taban (kâime), diğeri de yüksekliktir (amûd). biçiminde tanımlanmaktadır.

Eserde genel terimler verildikten sonra diğer geometrik şekiller tanıtılmaktadır. Eserde tanıtılan ilk şekil daire olarak verilmiştir. Dairenin yardımcı elemanlarından olan yarıçap, çap ve kiriş terimleri de eserde tanıtılmaktadır. Eserde tanıtılan şekillerin resimleri de verilmektedir. Günümüz ortaöğretim matematik öğretiminin içerisine yerleştirilen geometri öğretiminde de öğretim şekiller üzerinden yapılmaktadır. $\mathrm{Bu}$ biçimde yapılan öğretimde somutlaştırma yapılarak öğrenen kimsenin anlamlandırması ve yeni kavramları şemasının oluşturulmasını kolaylaştırılmak hedeflenmektedir. Eserde bahsi geçen bir diğer şekil ise üçgendir. Üçgenin tanımı verildikten sonra üçgenin çeşitleri tanıtılmıştır. Eşkenar üçgen, ikizkenar üçgen ve çeşitkenar üçgen olarak sınıflandırılmıştır. Bu sınıflandırma 'çizgi' olarak atfedilen üçgenin kenarlarının özelliklerine göre yapılmıştır. 
Üçgenlerin bir başka sınıflandırılması dik açılı, geniş açı1ı ve dar açılı üçgen olarak verilmiştir. Bu sınıflandırma 'zâviye' olarak isimlendirilen açıların özelliklerine göre isimlendirilmektedir.

Bundan başka eserde kare (murabba), dikdörtgen (müstatîl), eşkenar dörtgen (muayyen) ve paralelkenar (şebîh bi’l-muayyen) cisimlerinin açıklamaları verilmektedir. $\mathrm{Bu}$ şekillerin yardımcı elemanları olan köşegen verilmektedir. Eserde, Dörtgenlerden sonra beşgenler, altıgenler gelir ve bu şekilde sonsuza kadar devam eder. Bu şeklin (çokgenin) alanı sınırlandığında dairesel şekil meydana gelir.' Biçiminde yapılan açıklamalarda çokgenlerin kenar sayılarının sonsuza yakınsamasından dairenin oluşacağı ifade edilmektedir. Asırlar önce geometrik şekiller üzerinden verilen bu açıklama 'limit' kavramının açık bir uygulaması olarak günümüzde görülmektedir. $\mathrm{Bu}$ mana da o dönemde sonsuzluk kavramı üzerinde matematiksel mana da düşünüldüğünü ifade etmektedir. Çokgenlerin kenarlar sayısının sonsuza yakınsamasından sonra çember şeklinin oluşması günümüz matematik öğretiminde ifade olarak kullanılsa da teorik k1smindan bahsedilmemektedir.

Eserde 3 boyutlu cisimler derinlik kavramı ile ifade edilmiştir. Bu mana da ilk cisim olarak küre tanımlanmıştır. Küre şeklinin tanımından sonra kürenin kesilmesinden bahsedilmekte ve oluşan şeklin çember olduğu ifade edilmektedir.

Eserde bu terimlerden başka koni (mâhrut), dik koni (mahrut kâim), kesik koni (mahrut nâkıs), tanımları verilmiştir.

Eserde farklı olarak 'eğer yumurta şekli merkezi etrafında döndürülürse yumurta cismi (beydıyyu) meydana gelir.' biçiminde tanımlanan yumurta cismine yer verilmiştir. Günümüz ortaöğretim matematik öğretiminde böyle bir şekil mevcut değildir.

Eserde bu terimlerden başka çokgen silindir, çokgen koni ve üçgen prizması, küp cisimlerinin tanımları verilmiştir.

$\mathrm{Bu}$ tanımlar verildikten sonra, 'Mesâha ile ilgili verilen bu mukaddimeden sonra deriz ki: Mesâha; düz bir yüzeyde farz edilen çizgi ve kısımlarının örneklerini araştırmaktır. Çizgi (doğru) veya onun benzerleri ve kısımları araştırılıyorsa çevre, yüzey veya benzerleri ve kısımları araştırılıyorsa kare, cisim veya benzerleri ve kısımları araştırılıyorsa küp gibi cisimler söz konusudur. Allah'ın izni ile doğruya en yakın araştırma yollarını vermek istiyoruz.' Biçiminde yapılan açıklama öğrenen için neye ihtiyacı varsa öğrenmesi geçen konu kısımlarını ifade etmektedir. Bu açıklama eserde 
anlatılan kısmın bir özeti olarak düşünülebilir ki öğrencinin konu bütünlüğünü fark etmesi bakımından önem sağlamaktadır. Yine eserde dönemin değer yargılarının esere taşındığı görülmektedir.

Eserde geometrik şekillerin ve yardımcı elemanlarının tanıtılmasından sonra bu şekiller üzerinde hesaplamalar verilmektedir.

Eserde, Doğru, iki noktayı birleştiren en kısa çizgidir. Ĕ̆riye gelince doğrunun karşıtı olması cihetiyle ortaya konulması mümkün değildir. Ancak dairenin çevresi ile irtibatlandırllarak sunulabilir. Arşimet makalesinde, her dairenin çevresinin çapına nispetinin 22'nin 7'ye nispeti olduğunu açıklamıştır. Biçiminde yapılan açıklamalarda öncelikle doğru ile ilişkilendirerek eğrinin sezgisel tanımı yapılmıştır. Ancak eğrinin tanımında olan eksikliklerden dolayı eğrinin açıklaması günümüzde ifade edilen $\pi$ (pi) sayısı ile yapılmıştır. Ortaöğretim matematik müfredatında da dairenin çevresi bu şekilde ele alınır. Burada farklı olarak hesap işlemleri ile bulunmasının yanında dairenin çevresinin ölçme aracı ile bulunması da anlatılmaktadır.

Eserde yüzeylerin alanlarının ölçülmesine gelince üçgenin alanı, karenin alanı, dikdörtgenin alanı, eşkenar dörtgenin alanı günümüz ortaöğretim matematik öğretiminde de aynı biçimde gösterilmektedir. Bunun dışında eserde paralelkenarın ve yamuğun alanı, paralelkenar ve yamuk için yükseklik çizerek değil, paralelkenarı üçgensel bölgelere ayırarak hesaplanmaktadır. $\mathrm{Bu}$ da önce bilinen üçgenin alan hesaplamalarından yararlanılarak paralelkenarın ve yamuğun alanının hesaplandığı görülmektedir. Paralelkenarın alanının bu şekilde verilmesi, ortaöğretim matematik kitabında da mevcuttur. Ancak bu yöntem genellikle paralelkenarın alanının bulunmasın ek yöntem olarak verilmektedir. Eserde çokgenlerin alanının hesaplanmasında yine çokgenlerin uygun bölgelere ayrılarak hesabı yapılmaktadır. Çokgen olarak beşgen ve altıgen üzerinden örneklendirmeler verilmiştir. Çokgenlerde daha fazla kenarlı çokgenlerin bahsi geçmemektedir.

Ortaöğretim matematik müfredatının uygulaması olan matematik kitabında çokgenlerin alanı bu şekilde verilmemektedir. Daha çok formül olarak verilmektedir. Burada verilen yöntem ek yöntemler ve soru çözüm stratejileri olarak verilmektedir. Çünkü bu yöntem soruların çözümü açısından oldukça pratik ve anlaş1labilirdir. Günümüz matematik kitaplarında verilen birçok formül kalabalığından korku duyan öğrencilerin matematikten uzaklaştıkları ve korkunun matematik öğretimini engelleyen 
en önemli faktör olduğu bilindiğinden bu gösterim şekli en basit olan üçgenin alan hesabı ile yapılması öğrencinin yükünü hafifletecektir.

Çemberin alanının hesaplanması, yarıçapının karesi ve 22/7 ile çarpılması ile bulunmuştur. Bu hesap işlemi yaklaşık bir sayı alınarak yapılan hesaptan daha geçerli bir yöntemdir. Oval şekil, ikiye bölünmüş ve oluşan yarım daire parçalarına benzeyen şekillerin alanı için yarım daireden küçük şekillerin alanlarından yararlanılarak hesap yapılacağından bahsedilmiştir. Günümüz matematik öğretiminde bu şekilde düzgün olmayan şekillerin alanı fonksiyon olarak ifade edildikten sonra integral kullanılarak hesaplanmaktadır. Eserin ilerleyen kısımlarında, hilal şeklinin alanı, Dik (Dairesel, Dönel) ve eğik koninin yanal alanı, kesik ve çokgen koninin yanal alanları, dik (dairesel) ve eğik silindirin yanal alanları, çokgen silindirin yanal alanı şekiller parçalara ayrılarak önceki bilinen alanlardan yararlanılarak hesabı yapılmıştır.

Eserde, 'küre, küre dilimi ve küre parçasının yüzey alanlart:
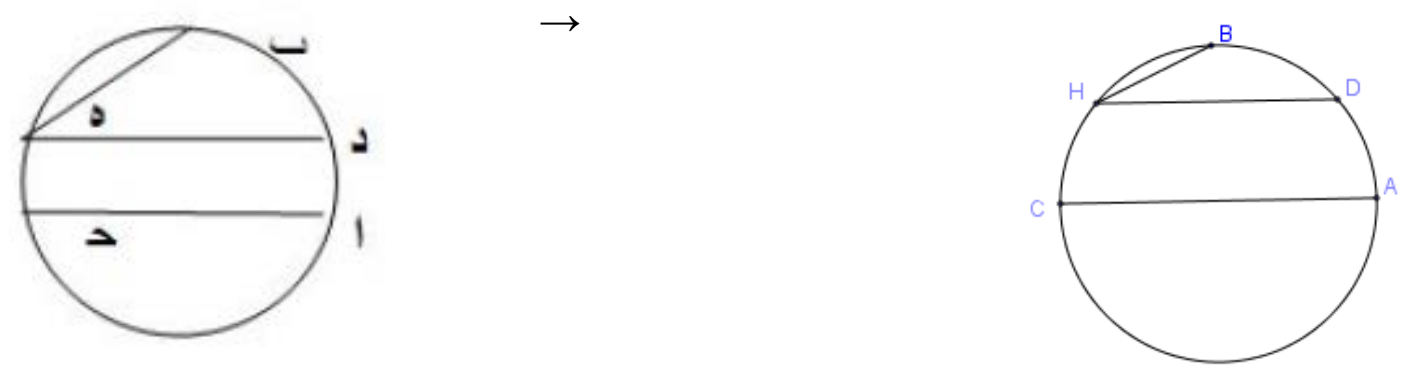

$|A C|$ Dairenin çapıdır. Buradaki (DBH) parçasının alanını bulmak için çap ile (DBH) yayı çarpılmalıdır. (DHCA) parçasının alanını bulmak için ise önce (ADBHC) parçasının alanı bulunur. Sonra (DBH) parçasının alanı bulunur ve en sonunda da $(A D B H C)$ 'nin alanından (DBH) 'nin alanı çıkarılır.' Biçiminde açıklanmıştır. Günümüz ortaöğretim matematik öğretiminde de farklı yöntemlerle gösterilse de sorunun çözümü bu biçimde de verilmektedir.

Eserde günümüz ortaöğretim matematik öğretiminde verilmeyen ezec ve tâk isimleri ile anılan bazı geometrik şekiller mevcuttur. Bu şekillerin öncelikle tanımı yapılmış ve ardından alanının bulunması verilmiştir. Bu şekiller aynı zamanda eserde çizilmiş olarak da verilmiştir. Eserde, 
'Ezec'in dış yüzeyinin alanı; dış yayı ile uzunluğunun çarpılması

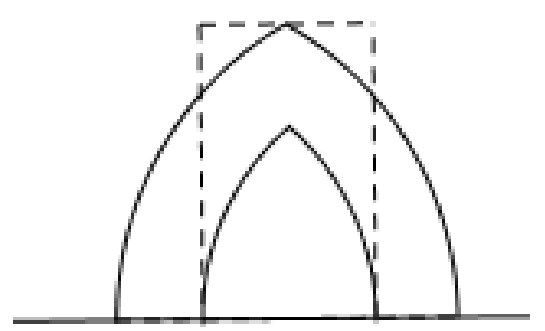
sonucu elde edilir. İç yüzeyinin alanı ise; iç yayı ile genişliğinin çarpılması sonucu elde edilir. 'Ezec'in yüzünün alanına gelince; yaylarının yarısının toplamı ile yüksekliğinin çarpılmasıyla bulunur.

Burada 'ezec' in hesaplaması ve şekli yamuğa benzemektedir. Şekildeki yamuğun içerisine dikmeler ile köşegeni çizilmiştir. Böylece şekil dört üçgene bölünmüştür.'

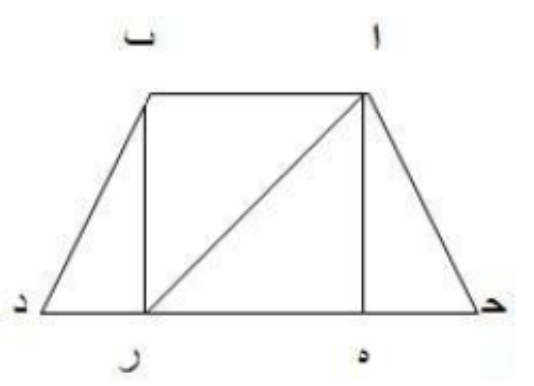

Tek tek tüm üçgenlerin alanlart bulunabilir. En sonunda da tüm üçgenlerin alanı toplanarak yamuğun alanına ulaşılır. 'Tâk'ın alanını hesaplamak da aynen böyledir. Çünkü 'ezec' ve 'tâk' arasında 'tâk'ın boyunun daha kısa olması hariç hiçbir fark yoktur.'

Tüm bunlar bilinen yüzeylerin alanlarının beyanıdır. Hiçbir yüzey parçalarına benzemez ve Allah'ın indindeki ilim ve hakikatteki gibi bir ölçmenin yolu yoktur.'

Eserde bu şekillerin alanlarının bulunması o dönemde matematiğin hayata uygulanmasının önem arz etmesinden kaynaklanmaktadır. Bu şekillerde dönemin değer ve inanç yargılarına göre biçimlenen mimari yapıların şekilleri olduğundan önem arz etmektedir

Düzgün geometrik şekillerinin hacminin hesaplanması uzunluk, genişlik ve yüksekliğin çarpılması ile mümkündür. Günümüz matematik müfredatında her düzgün geometrik şekle göre farklı olarak verilmektedir. Burada düzgün geometrik şekillerin hacmi için genel bir yaklaşım verilmiştir.

Eserde, 'Üçgen Prizmasının hacmi: Onu tamamlayan paralel kenar cismin hacminin yarısıdır.' Biçiminde yapılan açıklama ile üçgen prizmasının hacmi, paralelkenar cismin hacmine bağlanmıştır.

Ortaöğretim matematik kitabında böyle bir anlatım mevcut değildir. Bu anlatımın eksik olduğu da açıkça ortadadır.

Eserde, diğer bütün cisimlerin hacimleri sırası ile açıklanmıştır. 
Eserde konu anlatımı ve açıklaması sonlandığında, bu ilmi anlamak ve öğrenmek için nelere dikkat edilmesi gerektiği ve nasıl çalışılması gerektiği hakkında şu şekilde bir yorum yapılmıştır;

Uyarl (Bil ki):

Hesâbın şartı; zihni boşaltmak (hesab dışındaki şeylerden), dikkat, tahkik ve düşünce gücü ile birlikte çalışmaya güvenmek ve yorgunluk ve usanç halinin olmadiğı zamanlarda çalışılmasıdır. Bilhassa bizim bu kitapta anlattığımız cetveller ile çalışman bir ay veya daha fazla sürse de cetvelleri tekrar ederek ezberle ve bunları ögrendiğinden emin ol. Belki bu durum (süre) bize hastır. Bu fenni öğrenmeye azmetmek să̆lamalara güvenmek değil kararlılıkla çalışmaya devam etmektir. Hesab doğru olursa să̆lama da doğru olur. Sağlama doğru olmazsa hesab da doğru olmaz. Să̆lamanın doğru olması hesabın da doğru olduğunu göstermez. Hesap doğru olmazsa să̆lama da doğru olmaz. Hesapta hata olmasına rağmen sağlama ve hesap birbirlerine uygun olabilirler. Ancak sağlama, zihin karlşıklığı ve işlemin doğruluğundan emin olmak açılarından faydalıdır ve temel husus zikrettiğimiz gibidir. Başarı, cömertliğin bahşedicisi ve cömertlikle hayrı yayandandir.

Yapılan bu açıklamalar öğreneni yönlendirmekte ve bahsi geçen ilmi öğrenmesini kolaylaştıracak yollar göstererek cesaretlendirmektedir.

\section{Şemsiyye fi'l-Hisâb adlı eserin medreselerde okutulan bir kitap olma hususunda 2017 Ortaöğretim Matematik Dersi Öğretim Programına yönelik Milli Eğitim bünyesinde bulunan ve okullarda okutulan ders kitapları arasında benzerlik ve farklılıklar yönelik bulgular}

Araştırmanın ikinci araştırma problemi olarak 'Şemsiyye fi'l-Hisâb adlı eserin medreselerde okutulan bir kitap olma hususunda günümüz Milli Eğitim bünyesinde bulunan ve okullarda okutulan ders kitapları arasında benzerlik ve farklılıklar nelerdir?' sorusu ele alınmıştır. Bu bölümde bu sorunun cevabı ele alınacaktır.

Eserin medreselerde okutulan bir kitap olarak günümüzde kullanılan matematik kitabı açısından değerlendirmek için öncelikle yapı benzerliği bakımından incelemek uygun olacaktır. Bir kitabın yapı benzerliğinden kasıt, o kitabın içerdiği konu ve başlıkları bakımından incelemektir. 
Eserin yapısı incelendiğinde; günümüzde aritmetik, cebir ve geometri olarak isimlendirilen konuların varlığı dikkat çekmektedir. Günümüz matematik kitaplarında ise bu konu başlıklarının Öğrenme Alanı olarak isimlendirilerek Sayılar ve Cebir, Geometri ve Veri, Sayma ve Olasılık olarak üç kısma ayrıldığı görülmektedir. Şekil açısından bakıldığında bu başlıkların benzer olduğu söylenebilir. Farklı olarak günümüzde öğretimine yer verilen Veri, Sayma ve Olasılık Öğrenme alanının bu eserde mevcut olmadığı görülmektedir.

Eser içerik açısından incelenmek istenirse eserin yapısının neler içerdiğini incelemek yeterli olacaktır. Eserde matematik öğretimine başlamadan önce bir önsöz verilmektedir. Önsöz kısmında,

İlim ve edeb tahsil edenler İlm-i Hisâb’a ilgisiz kalamazlar. Ülke ve devlet işlerinin kontrolü ile uğraşanlar, vezirler ve kâtipler ona muhtaçtırlar. Matematik her açıdan önemli ve ihtiyaç duyulan bir ilimdir.

Biçiminde verilen açıklamalar ilmin yararlılığından bahsetmektedir. Günümüz ortaöğretim matematik kitaplarında bu şekilde bir önsöz son yapılandıran ortaöğretim müfredatı ile gündeme gelmiş ve kitaplarda yerini almaya başlamıştır.

Eserin geometri konusunun içeriği incelendiğinde günümüz matematik kitaplarında var olan birçok konunun var olduğu görülmektedir. Temel geometri terimler bu eserde de verilmektedir. Ancak yine çoğu terim tanımlanmaya çalışılmıştır. Zaten matematik ve öğretiminde bazı terimlerin tanımsız olarak atfedilmeleri çok sonra gerçekleşmiştir.

Eserin geometri konusunun içeriğinde üçgenlerin genel özellikleri verilmiş ancak bu üçgenlere ait birçok teorem verilmemiştir. Dörtgenlerden ve çokgenlerden aynı şekilde bahsedilmiş, genel özellikleri verilerek alan ve hacim hesabı yapılması açıklanmıştır. Günümüz matematik kitaplarında terimlerin açıklanmasından sonra üçgenler konusu birçok özelliği ile verilir ve oldukça önemli olarak kabul edilmektedir. Yine günümüz matematik kitaplarında dörtgenler ve çokgenler konusunda birçok teoremi içerisinde barındırarak verilmektedir. Genel mana da incelendiğinde geometri öğrenme alanında verilen eser temel özellikleri vermekle yetinmektedir.

Aşağıda bazı örnekler verilmiştir. 

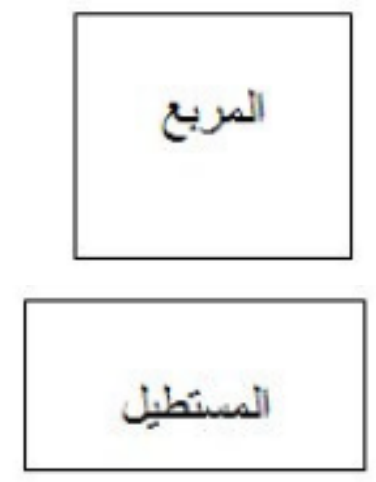

Eğer şekil 4 eşit çizgi ile sınırlanmış ve oluşan 4 açı da dik açı ise bu şeklin adına kare (murabba) denir.

Eğer şekil 4 dik açıya sahip ve 4 kenarının karşılıklı olanları birbirine eşitse bu şekle dikdörtgen (müstatîl) denir.

Eğer şeklin 4 kenarı eşit olur da açıları dik olmazsa bu şekle eşkenar dörtgen (muayyen) denir.

4 kenarlı bir şeklin açıları dik olmaz, kenarlarının da

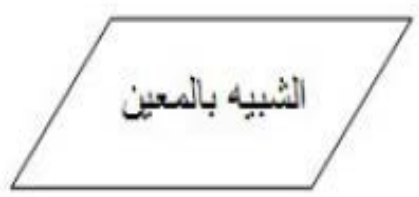

karşılıklı olanları birbirine eşit olursa bu şekle paralelkenar (şebîh biecl-muayyen) denir.

Eserin konuların anlatımında kullanıldığı dil ve üslubu pedagojik açıdan incelemek gerekirse, bu eseri kullanan öğrencilerin seviyesi göz önüne alınmalıdır. Eser ele aldığı her konunun en temelinden başlamaktadır. Bu da öğrencinin eksik bilgilerinin giderilmesine olanak sağladığı anlamına gelmektedir. Eserde o dönemin koşullarına göre oldukça sade bir dil kullanılmaya çalışılmıştır. Yazar bu amaç ile yola çıktığını eserin önsözünde de ifade etmektedir. Konuların anlatımında her açıklama örneklendirilmiş ve anlaşılması sağlanmıştır. Günümüz matematik kitaplarında bulunan örnek sayıları ile elbette aynı değildir. Ancak o döneme göre verilen örnek sayıları yeterli gözükmektedir. Eserde konuların anlatımında notasyon kullanılmaktan mümkün olduğunca kaçınmak istenmiştir. Konuşma dili ile konu anlatımı yapılmıştır. Bu kolay anlamayı sağlasa da işlemler arttığında anlamayı zorlaştırmaktadır.

Eserin konuların anlatımında atıflarda bulunması konunun kaynağını göstererek öğrenciyi araştırmaya yönlendirmesi açısından önemlidir. Anlatılan hesap konularında öğrenciler için birden fazla yol göstermesi ise öğrencide farklı yöntemlerin bulunabileceğini göstermesi açısından önemlidir. 
Günümüz matematik kitaplarında farklı yöntemler verme durumunu soru üzerinde görmek mümkündür. Ancak konunun anlatım aşamasında çok sık rastlanmamaktadır. Çoğu sorunun çözümünde de öğrencinin pedagojik özelliklerine uygun işlemsel açıdan en sade çözüm yolu tercih edilerek öğrenci yönlendirilmektedir.

\section{Şemsiyye fi'l-Hisâb adlı eserde geometri hesaplarında kullanılan yöntem ve} tekniklere yönelik bulgular

$\mathrm{Bu}$ problem cümlesi temel alınarak eser incelenmiş ve probleme çözüm aranmıştır. Eserin geometri öğretiminde öncelikli olarak geometrik şekillerin tanımı verilmiştir. $\mathrm{Bu}$ tanımlar verilirken öğrencinin yaşadığı dönemin kültürel ve sosyal yapısına uygun olarak ilişkilendirmeler yapılmıştır. Bu sayede günümüz öğretim programında yer alan hayata yakınlık ilkesinin uygulandığı görülmektedir. Aynı zamanda eserde yer alan şekillerin gerçek ölçüm araçları ile ölçümlerinin yapılmasından bahsedilmiştir. Böylece öğrencinin materyal kullanması sağlanmış ve öğrencinin geometrik şekillerle birebir etkileşime girmesi sağlanmıştır.

Şemsiyye fi'l-Hisâb adlı eserde geometri öğretimi ile 2017 Ortaöğretim Matematik Dersi Öğretim Program'ındaki geometri öğretimi arasında farklılıklara yönelik bulgular

Eserin geometri öğretiminde dönemin teknolojik şartlarına ve ilim faaliyetlerine uygun olarak şekil kullandığı ve şekil üzerinden anlatım yaptığı görülmektedir. Ancak eserde verilen teoremlerin ispatı yapılmamıștır. Günümüz geometri öğretiminde verilen birçok teoremin ispatı verilmektedir. $\mathrm{Bu}$ eserde Bunun yerine eserde bu ispatlara ulaş1labilecek kaynak gösterimi yapılmıştır. Arşimet ve Öklid, kaynak göstermede kullanılan iki isim olarak eserde geçmektedir. Eserde şekiller üzerinde kullanılan sembol ve işlemlerde Arapça rakamlar kullanılmıştır. Şekil üzerinde ki harflendirmeler ise yine Arapça harflerinden kullanılmıştır. Günümüz modern matematiğinde bu işlemler için Latin harfleri ve modern matematik sembolleri kullanılmaktadır.

Eserde geometri öğretiminde günümüzden farklı olarak bazı cisimler tanıtılmış ve bu cisimlerin alan ve hacim hesabı verilmiştir. Eserde, beydıyyu (yumurta cismi), ihlîlicî (oval), hilâli (hilal şekli) cisimleri tanıtılmıştır. $\mathrm{Bu}$ cisimlerin öğretimi günümüz 
ortaöğretim matematik öğretimi programında yer almamaktadır. $\mathrm{Bu}$ cisimlerden beydiyyu cisminin açıklanması oldukça belirsizdir. Cismin açıklanmasında bir yumurtanın kendi çevresi etrafında döndüğünde oluşan şekil olarak ifade edilmiştir. Ancak bu açıklama değişken bir nesneye bağlandığı için uygun değildir. Bugün günümüz müfredatında bu şekli benzer olarak elips örnek verilebilir.

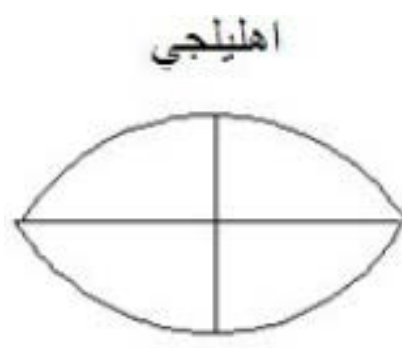

Yarım dairenin yayından daha küçük iki yayın karşıt yönlerden birleşerek oluşturduğu şekle oval (ihlîlicî) denir.

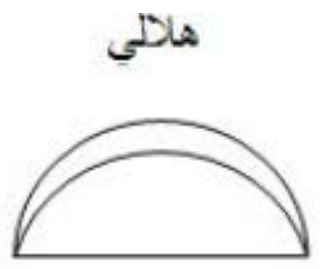

Bir çap üzerine iki farklı yay çizildiğinde 2 yay arasında kalan şekle hilal şekli (hilâlî) denir.

\section{Tartışma, Sonuç ve Öneriler}

(Yel, 2010) Hulasat Al-Hisap Adlı Eserin Geometri Öğretimi Açısından İncelenmesi ve Yeni Müfredat ile Karşılaştırılması adlı yüksek lisans çalışmasında, "Eserin geometri ve cebir anlatan kısmında konu anlatımı ile ilgili çözümlü örneklere yer verildiği ve sık sık şekiller kullanıldığını" tespit etmişler. "Fakat eser pedagojik amaçla yazılmış olmasından dolayı örneğin geometrik cisimlerin alan ve hacimlerini bulmak için kullanılan yöntemler detaylı olarak anlatılmak istendiği için anlaşılmasını zorlaştırdığını ve ayrıca bu yöntemlerin bugün ki gibi semboller kullanılarak formulize edilmediğini” gözlemlemişlerdir.

(Ceylan, 2017) Enderun Mektebi’ndeki Matematik Öğretiminin Miftâhü'l-Hisâb Işı̆̆ında İncelenmesi ve Örnek Uygulamalarla Değerlendirilmesi adlı çalışmasında "Enderun Mektebieende ilk seviyeden ileri düzeye kadar matematik eğitim ve öğretimine dair belirgin bir programın kullanıldığını söylemek mümkün olmadığg, bu programın içeriği okutulan kitap ve dersi veren müderrisin matematik bilgisi ile sınırlı olduğu ve 
Tâk Çizimi ve sözel temsili geometri problemlerinin öğrenci tarafından görsellenmesi ve çözüme bu şekilde gidilmesinin önemini” tespit etmiştir.

Şemsiyye Fi'l-Hisâb adlı Matematik Risalesinin öncelikle transkripsiyonu yapılmış ve ardından günümüz Türkçe'sine çevrilmiştir. Eserin matematik risalesi olduğu göz önüne alındığında eser içerisinde bulunan ve o dönemde kullanılan birçok matematiksel terim ve semboller modern matematikte kullanılan terim ve sembollere dönüştürülmüştür.

Şemsiyye Fi'l-Hisâb adlı eser, Dibace ve mukaddime kısımları ile birlikte 2 Fen'den oluşmaktadır. Birinci Fen kısmı 2 bâb’tan oluşmakta ve ikinci Fen kısmı ise 4 bâb'tan oluşmaktadır.

Eserde Geometri öğretimi ikinci fenn, üçüncü bâb’ta yer almaktadır. Bu bölümde somut olarak görülebilen cisimlerin tanıtımı ve bu cisimlerin temel ve genel özellikleri verilmiştir. Yine bu şekillerin yüzey alanlarının hesabı ve hacim hesaplamaları yapılmıştır. Bu bölümde anlatılanlar genel itibariyle yüzeysel kalmıştır.

Eserin genel hatları incelendiğinde yazılma amacına uygun olarak şekillendiği görülmektedir. Ayrıca eserin konu işleyiş sırası bakımından ele alınması da kolayda zora ilkesinin tercih edildiğini göstermektedir.

Eserin anlatımının dönemin ilim dili açısından düşünüldüğünden sayıların ve sembollerin kullanılmayarak sözel ifadelere başvurulması öğrencilerin anlamlandırmasında katkıda bulunmaktadır. Yine de bu anlatım şekli uzun hesap gerektiren konularda uygun olmamaktadır.

Eserin konuları tanıtımında sürekli olarak bilinen konuşlara atıf yapılarak yeni konunun anlatılması, eserde bilinenden bilinmeyene ilkesini dikkate aldığı söylenebilir. Eserde geçen bazı temel teoremlerin Arşimet ve Öklid gibi ilim insanlarının yazmış olduğu eserlere yönlendirme mevuttur. Bu da öğrencinin daha fazlasını öğrenme isteğini yerine getirebileceği kaynak edinme ihtiyacını ortadan kaldırmaktadır.

Günümüz matematik konularının anlatımı ile karşılaştırıldığında, eserde günümüz modern matematik sembolleri veya çözüm yöntemleri kullanılmadığı için kolay kısımlar daha da zorlaştırılmıştır. Fakat eser içerisinde geçen kurallar ve teoremler bakımından herhangi bir ispat yapılmaması, eserin yazılma amacının temel başvuru kitabı olarak pratikte kullanılacağı iddiasını desteklemektedir. 
(Değirmendere, 2009) Kuyucaklızâde M. Âtıf Ve Matematiğe Dair "Nihâyetü'lElbâb Fî Tercemeti Hulâsati'lhisâb” Adlı Eseri (Metin ve Değerlendirme) adlı eser inceleme çalışmasında “Osmanlı Devleti’nde matematik çalışmaları ve eğitimi, diğer bilim dallarında olduğu gibi üç ana döneme ayrılabildiği: Bu dönemler; teşekkül dönemi (1300-1453), gelişme dönemi (1453-1600) ve klasik bilim geleneğinde duraklama ve modern bilim geleneğinin başlaması (1600-1923) dönemleri” olduğunu belirtmişlerdir. (Baga, 2007) çalışmamıza ilham olan Nizâmuddin Nîsâbûrî ve Şemsiyye Fi'l-Hisâb Adlı Matematik Risâlesinin Tahkik, Tercüme ve Tarihi Bir Değerlendirmesi adlı eser inceleme çalışmasında "Şemsiyye orta seviye ve hacimde, açıklamalı örnekleri ile bir öğrenci için ideal nitelikte bir eser” olduğu, “Eser Ali Kuşçu’nun talebelerinden Bircendî ve Kirmânî tarafından şerhedilmiş ve Semerkant matematik-astronomi okulunda okutulmuş ve bundan başka eser Ali Kuşçu'ya yani 15. yy’ın ortalarına kadar Osmanlı medreselerinde hesap kitabı olarak okutulduğunu" ortaya çıkarmıştır.

Eserin tercümesi ile ilgili sonuçlar Nizâmuddin Nîsâbûrî ve Şemsiyye Fi'l-Hisâb Adlı Matematik Risâlesinin Tahkik, Tercüme ve Tarihi bir Değerlendirmesi isimli Elif Baga tarafından yazılarak hazırlanan yüksek Lisans Tezi ile paralellik göstermektedir.

Eserin günümüz matematik öğretimi ve dönemin matematik öğretiminin karşılaştırılmasından elde edilen sonuçlar Nurten Yel tarafından hazırlanan Hulasat AlHisab Adlı Eserin Geometri Öğretimi açısından İncelenmesi ve Yeni Müfredat ile Karşılaştırılması Yüksek Lisans Tezi ile paralellik göstermektedir.

\section{Öneriler}

Araştırmanın bu bölümünde Şemsiyye Fi'l- Hisâb adlı Matematik risalesinin geometri öğretiminin incelenmesi ve günümüz matematik öğretimi ile karşılaştırılmasının yapılması ile elde edilen bulgular ve sonuçların gösterdirdiği yol doğrultusunda bazı önerilere yer verilmektedir.

(Yel, 2010) "Hulasat Al Hisab isimli eserde yer alan fakat günümüz matematik kitaplarında bulunmayan "hilâlî, nâlî, ihlilcî, şelcemî" gibi bazı geometrik kavramlara ve tanımlara günümüzdeki karşılıkları kullanılarak yer verilebileceği ve ayrıca okullarda, eserde yer verilen "hilâlî, nâlî, ihlilcî, şelcemî" gibi geometrik şekillerin alan hesabı ile ilgili uygulamalar yaptırılabileceğini”’ belirtmiştir. Benzer biçimde Şemsiyye Fi'l Hisâb adlı Matematik Risalesinin içerisinde bulunan farklı geometrik şekillerin Liselerde matematik derslerinde ufak uygulamaları oluşturularak değerlendirmesi yapılabilir ve bu 
alana ilgi çekilmesi sağlanabilir. Nizâmuddin Nisâburî'nin Şemsiyye Fi'l-Hisâb'1 gibi gerek Fatih döneminde olsun gerekse Osmanlı Devleti’nin diğer dönemlerinde olsun medreselerde okutulan diğer kitapların incelenmesi yapılabilir.

\section{Makalenin Bilimdeki Konumu}

Matematik ve Fen Bilimleri Eğitimi/Matematik Eğitimi

\section{Makalenin Bilimdeki Özgünlüğü}

Matematik tarihi ve kavramların gelişimi bakımından önceki dönemlere ait matematik öğretimi yöntem ve materyal kullanımının bilinmesinin önemli olduğunu düşünmekteyiz. Özellikle kendi medeniyetimize ait kaynakların incelenmesi ve yeni nesillere sunulmasının faydalı olduğu kanaatindeyiz. Elif BAGA, Nizâmuddin Nîsâbûrî ve Şemsiyye Fi'l-Hisâb adlı Matematik Risâlesinin tahkik, tercüme ve tarihi bir değerlendirmesini yüksek lisans tezi olarak çalışmıştır. Biz de aynı eserin yeniden tercümesini yaparak, 2017 yılına ait Matematik Müfredatıyla kıyaslanmasına yönelik bir çalışmanın geometri kısmını buraya taşıdık.

\section{Kaynaklar}

Baga, E. (2007). Nizâmuddin Nîsâbûrî ve Şemsiyye Fi'l-Hisâb Adlı Matematik Risâlesinin Tahkik, Tercüme ve Tarihi Bir Değerlendirmesi Yüksek Lisans Tezi. Sakarya: Sakarya Üniversitesi, Sosyal Bilimler Enstitüsü, Felsefe ve Din Bilimleri Ana Bilim Dalı.

Baki, A. (2014). Kuramdan Uygulamaya Matematik Eğitimi. Ankara: Harf Eğitim Yayıncıllı̆̆ Demir, R. (2003). "Türkiye'de Bilim Tarihi Araştırmalarının Gelişimine Genel Bir Bakış", Türkiye'de Bilim Tarihi Araştırmalarının Dünü ve Bugünü. Ankara Üniversitesi, Dil ve TarihCoğrafya Fakültesi Yayınları, Ankara.

Demirtaş, A. (1986). Ansiklopedik Matematik Sözlü̆̆̈̈. Bilim Teknik Kültür Yayınları, Ankara. Fazlıoğlu, İ. (2009). İthaf'tan Enmûzec'e Fetih'ten Önce Osmanlı Ülkesi'nde Matematik Bilimler. Uluslararası Molla Fenârî Sempozyomu, (s. 131-132). Bursa.

Göker, L. (1989). Matematik Tarihi. Kültür Bakanlığı Yayınları, Ankara . 
Hızlı, M. (2008). Osmanlı Medreselerinde Okutulan Dersler ve Eserler. Uludă̆ Üniversitesi Illahiyat Fakültesi Dergisi, 25-46.

İzgi, C. (1997). Osmanlı Medreslerinde İlim. İstanbul: İz Yayıncılık.

Unat, F. R. (1964). Türkiye Eğitim Sisteminin Gelişmesine Tarhi Bir Bakış. Ankara.

Ülger, A. (2005). Matematiğin Kısa Bir Tarihi. Eğitim ve Düşünce Dergisi, 1.

Zeki, S. (2003). Âsâr-ı Bâkiye. Babil Yayınları, Ankara.

\section{Summary}

\section{Introduction}

The most notable educational institution in Islamic history were the Madrasas. The courses were conducted under the supervision of the students themselves and the fallow-up of the book selected for the course played a decisive role in passing the course. In this sense, the method of choosing textbooks was not applied the madrasas. Therefore, the works that were important for understanding the mathematics science of the period were taught and used in these Madrasas.

This study will be examined by Nizamedin Nisaburi, who was taught in madrasas in the Ottomon Empire, and his work titled El Şemsiyye Fi'l Hisâb will be evaluated in terms of mathematics science and education. In this sense, the work will be presented in terms of the history of mathematics, the structure of the in terms works of the period and the sources about the mathematical information of the period. It is important that this study will be examined in terms of mathematics education of the statement who grew up during the periods who ottoman civilization developed rapidly and ruled almost half of the World. In this study the history of mathematics and mathematics education in the treatise of mathematics called Şemsiyye Fi'l Hisab is examined in terms of today's mathematics, science activities and education about algebra will be examined.

Within the framework of education curriculum. What are contents of the math subjects included in the Şemsiyye Fi'l Hisab and how these subjects are taught.

The aim of this course is to examine the Şemsiyye Fi'l Hisâb from the point of Wiews of the mathematics curriculum which has been restructured by the Ministry of Education within today’s National education is terms of being a book taught in Madrasas. 
Şemsiyye Fi'l Hisâb is to examine the teaching of arithmetic with the content of algebra and examine these subjects in terms of the mathematics curriculum, which has restructured by the ministry of education in 2017.

\section{Method}

Document analysis model was used in search. For this method, the related parts of Nizameddin Nisaburi's Şemsiyye Fi'l Hisâb were transcribed in to Latin Letters. Translation of the work translated in to Latin Letters in to modern Turkish has been provided.

For the 2017-2018 academic year, the contents of the Şemsiyye Fi'l Hisâb in the contents of the secondary mathematics curriculum structured by the ministry of education were examined in terms of teaching algebra.

\section{Result, Discussion and Conclusion}

First the definition of exponent and the definition of square root are given in the work. This ranking is also expressed in the 2017 secondary mathematic program. In the continuation of the work, different methods are given with in the cube root. In the same way, it is explained and examplified for square root and cube root in national numbers. It is important for the work to make references in the expression of the subjects to lead the students to research by showing the source of the subject. It is possible to question the state of giving different methods in today's mathematics book. However, it is very common in the expression phase of the subject in the solution of most problems, the students are guided by choosing the simplest method of solution from a transactional point of view that is appropriate to the pedagogical characteristics of student. 